\title{
Protecting the Maritime Zones from Pollution by Coastal State: A Legal Analysis of the Law of the Sea
}

\author{
Abdul-Nasser H. Hikmany, PhD Candidate \\ Ahmad Ibrahim Kulliyyah of Laws, International Islamic University Malaysia
}

\begin{abstract}
Pollution of the marine environment is a global issue as many economic activities are engaged via the maritime zones to the extent that $16 \%$ of the people live in the coast, $90 \%$ of trade goes by sea and $85 \%$ of the coast is developed while at the same time rising sea level by $3 \mathrm{~mm}$ every year. This study gives an analysis of the United Nations Convention of the Law of the Sea (UNCLOS) and how far it provides powers to the coastal state in protecting their maritime zones and preventing pollution. It concludes that the coastal states have sufficient powers to protect their marine zones against pollution caused by vessels ranging from detention, institute proceedings, receiving sufficient information and claiming monetary damages from an infringing vessel.
\end{abstract}

Keywords: maritime, zones, pollution, coastal, state, law, sea.

\section{Introduction}

One of the principal aims of the United Nations Convention of the Law of the Sea (UNCLOS), enacted in 1982 and which came into force in 1994 is the protection of maritime zones and prevention of marine pollution. The States, under UNCLOS, are therefore provided with different powers to control their marine zones depending on their jurisdiction.

The sovereignty of the coastal State "extends, beyond its land territory and internal waters". 1 The coastal State relates to territorial $\mathrm{sea}^{2}$ and "air space over the territorial sea as well as to its bed and subsoil," 3 contiguous zone $^{4}$ and the exclusive economic zone ${ }^{5}$ which also includes the ice-covered areas within the exclusive economic areas. ${ }^{6}$

A coastal State can also be referred to as the port State. ${ }^{7}$ The latter means "the State whose ports are visited by a vessel, to exercise specific legislative and enforcement powers over such vessels." ${ }^{8}$ In other words the port State refers "to the State (or States) to whose port or ports a vessel is proceeding." 9 The distinction can be drawn through article 218 of the UNCLOS in which the port State has jurisdiction to apply international rules and standards outside its internal waters, territorial sea or exclusive economic zones. The coastal State on the other hand, has jurisdiction to apply its laws and regulations within the coastal States' internal waters, territorial sea or

\footnotetext{
1 The United Nations Convention on the Law of the Sea (1982), art. 2 (1).

2 See $n 1$ above, art. 3.

${ }^{3}$ See $\mathrm{n} 1$ above, art. 2 (2).

${ }^{4}$ See $\mathrm{n} 1$ above, art. 33 .

5 See $\mathrm{n} 1$ above, art. 55.

${ }^{6}$ See $\mathrm{n} 1$ above, art. 234.

${ }^{7}$ M. Nordquist et al, The United Nations Convention on the Law of the Sea 1982: A commentary vol. IV, (London: Martinus Nijhoff, 1991), 260.

8 T. Keselj, 'Port State Jurisdiction of Pollution from Ships: The 1982 United Nations Convention on the Law of the Sea and the Memoranda of Understanding', Development \& International Law, (London: Taylor \& Francis, 1999), 128.

${ }^{9}$ See n 7, p. 260.
} 
exclusive zone, or on its continental shelf. ${ }^{10}$ For that reason, "a State may be able or even obliged to act in more than one capacity with respect to a given pollution incident." 11

Pollution of the marine environment is a global issue as many economic activities are engaged via the maritime zones, thus affecting the coastal States in one way or the other. The figures show that $16 \%$ of the people live in the coast, $85 \%$ of the coast is developed, the climate change in sea level rises by $3 \mathrm{~mm}$ every year and $90 \%$ of the external trade goes by sea. ${ }^{12}$ As long as $90 \%$ of trade goes by sea which also includes shipping activity and its impact on the marine environment is high, this study will therefore focus on the pollution caused by shipping. It has also been identified that " 1.47 million tons of infiltrate the oceans as a result of shipping operations." 13

\section{Outline}

This study has two sections: Section one gives a brief description of the coastal marine zones, pollution and types of marine pollution. The section ends with a discussion on protection of the coastal State against the mentioned types of pollution. The second section provides an in-depth analysis of the powers of the coastal State in respect of preventing the maritime pollution against vessels. It concludes that the UNCLOS has given sufficient powers for the coastal State in combating pollution caused by shipping.

\section{Section One: Pollution}

Every coastal State has sovereignty and corresponding duties starting from its baselines, its internal waters, ${ }^{14}$ territorial sea, ${ }^{15}$ archipelagic waters, ${ }^{16}$ exclusive economic zone (EEZ), ${ }^{17}$ continental shelf ${ }^{18}$ and the contiguous zone. ${ }^{19}$

Since one of the aims of UNCLOS is to protect the marine environment, it follows therefore that the coastal State has both the sovereignty and sovereign rights in the maritime zones to implement the UNCLOS provisions on the protection of the marine environment. Sovereignty should be differentiated with "sovereign rights" as sovereign rights gives the coastal State some powers depending on jurisdiction, such as applying policies and ensuring that the coastal State is not polluted. ${ }^{20}$

With respect to pollution, the UNCLOS in article 1 (4) defines pollution with respect to marine environment as follows:

the introduction by man, directly or indirectly, of substances or energy into the marine environment, including estuaries, which results or is likely to result in such deleterious effects as harm to living resources and marine life, hazards to human health, hindrance to marine activities, including fishing and other legitimate uses of the sea, impairing of quality

\footnotetext{
${ }^{10}$ See $\mathrm{n} 7$ above, p. 260.

11 See $n 7$ above, p. 261.

12 See a paper presented by Dr. R. Long, EU Maritime Policy UN-Nippon Foundation Law of the Sea Fellow Asia Pacific Alumni Meeting, (Tokyo: 2009).

${ }^{13}$ E. Louka, International Environmental Law, (Cambridge University Press: USA, 2006), p. 156.

${ }^{14}$ See $\mathrm{n} 1$ above, art. 8 .

${ }^{15}$ See $\mathrm{n} 1$ above, arts 3 and 2 (2)

16 See $\mathrm{n} 1$ above, art. 46.

${ }^{17}$ See $\mathrm{n} 1$ above, arts 56 (1) and 57.

18 See $n 1$ above, art. 76.

${ }^{19}$ See $\mathrm{n} 1$ above, arts 24 (2) and 33 (2).

${ }^{20}$ R. Dupuy and D. Vagnes, A handbook on the law of the sea, vol. 2, (Matinus Nijhoff: London, 1991), pp 1036 and 1215.
} 
for use of sea water and reduction of amenities. ${ }^{21}$

As the definition of marine environment under UNCLOS indicates, human beings are the main cause of marine pollution. States are therefore obliged to reduce and prevent marine pollution as well as to protect the marine resources. This obligation is stipulated under article 192 of the UNCLOS. Depending on the jurisdiction of the State, all States have the right to protect the marine environment while exploiting their natural resources as given under article 193 of UNCLOS. A line of obligation is therefore drawn between the coastal State preventing pollution and other States having the right of use.

In terms of pollution caused by shipping, they are a major threat to the marine environment as they cause toxic gases entering the sea. ${ }^{22}$ When toxic substances enter the sea, they destroy the ecological system of marine resources. For example, some may get killed, others may be affected in health, reducing their growth and slowing down their reproductive systems. ${ }^{23}$ These activities which endanger the marine resources are highly prohibited. Any navigation (including warships) which will prejudice the living organisms in the marine resources is restricted. The marine environment is also heavily destroyed during the wars. Experts have this to comment as from the outcomes of the Gulf Persian war:

The effects of the oil are devastating on wildlife. Tens of thousands of birds are dying, the shrimp and fishing industry are badly affected, and parts of the coral reef which have taken hundreds of years to form are destroyed. ${ }^{24}$

Controlling pollution from seabed activities is difficult comparing to pollution from land. ${ }^{25}$ The level of difficulties differs depending on the pollution caused. For example, the flow of dumps from one jurisdiction to another will depend on actions by both concerned States.

\subsection{Sources of the Maritime Pollution}

The UNCLOS has given six types of pollutions. These are found from article 207 to 212 of the UNCLOS. They are briefly explained below:

1. Pollution from land-based sources (Article 207): This article orders not only the coastal State, but all member States of the UNCLOS to prevent pollution of the marine environment from land activities such as wastes of dumping. The UNCLOS further elaborates that pollution of the marine environment must be prevented from rivers, estuaries, pipelines and outfall structures. ${ }^{26}$ In prevention and reduction of the pollution, States are adhered to abide on the UNCLOS, international and diplomatic rules. The

\footnotetext{
${ }^{21}$ This definition was adopted in 1976 through the Revised Single Negotiating Text (RSNT), Part III. See M. Nordquist et al, United Nations Convention on the Law of the Sea 1982 A Commentary, Vol. III, (Netherlands: 1993), 33.

${ }^{22}$ R. Churchill \& A. Lowe, The law of the sea, (Manchester: 1999), 353.

${ }^{23}$ See $\mathrm{n} 22$ above, p. 331.

${ }^{24}$ M. Ross, Environmental Warfare and the Persian Gulf War: 'Possible Remedies to Combat Intentional Destruction of the Environment', 10 Dickinson Journal of International Law 524, n 66 (1992): Experts of Britain's Royal Society for the Prevention of Cruelty to Animals, Gulf War Heightens Fears of Long-Term Impact on Climate, The Reuters Library, Report (Feb. 22, 1991) (LEXIS, Nexis library, Int'l file).

${ }^{25}$ See C. Reid, $3^{\text {rd }}$ edn. Nature Conservation Law, (Thomson: 2009), 52.

${ }^{26}$ See n 1 above, art. 207 (1).
} 
UNLCOS also harmonizes State's taking other policy measures such as enacting conventions or treaties. $^{27}$

2. Pollution from sea-bed activities (Article 208): This kind of pollution is subject to national jurisdiction as it is limited to seabed and subsoil of the States. The seabed and subsoil jurisdiction are mainly under the jurisdiction of the coastal State. The aim of this article is to prevent "damage by exploitation of the subsoil, seismic exploration in connection with oil prospecting, and leaks from pipelines." 28 Though the UNCLOS allows States to take their own measures as given under article 207 (1), but these measures must be "no less effective than international rules, standards and recommended practices and procedures." 29

3. Pollution from activities in the Area (Article 209): This article aims to prevent, reduce and control pollution of the marine environment from activities in the Area. ${ }^{30}$ The activities may be taken by a vessel, installation, structure or any other device. It deals with the marine zones beyond a national jurisdiction and therefore it is particular related to the flag States. ${ }^{31}$

4. Pollution by Dumping (Article 210): This article is concerned to all States. It deals with measures to be taken by States in order to reduce the release of toxic, harmful or noxious substances caused by dumping as stipulated under UNCLOS article 194 (3) (a). The main objective of this is to preserve and protect the ecosystem of the marine life. ${ }^{32}$ Due to its maritime zones within the territorial sea, exclusive economic zone or continental shelf, the coastal State has been given powers to authorise or prohibit any kind of dumping done by other States. ${ }^{33}$ The UNCLOS defines 'dumping' under article 1 (5) (b) and it also allows other regulatory measures to prevent pollution by dumping in marine environment.

5. Pollution from Vessels (Article 211): This article is designed to prevent pollution of the marine environment caused by vessels. ${ }^{34}$ Coastal States are mainly affected with this kind of pollution and the UNCLOS exclusively specifies certain measures which it can take to prevent itself. It must be noted that pollution from shipping activities can also include polluting the atmosphere as described in article 212 of the UNCLOS.

6. Pollution from or through the Atmosphere (Article 212): The UNCLOS prohibits any kind of pollution to the marine environment whether land or air based. The words "to the air space under their sovereignty and to vessels flying their flag or vessels or aircraft of their registry" clearly implies that vessels and air crafts must abide to prevent, reduce and control pollution of the marine atmosphere.

\subsection{Powers and Protection of Coastal States Against Pollution Under The UNCLOS}

With respect to preventing pollution of the marine environment against shipping activities, the UNCLOS gives the coastal State powers to detain, demand of information, institute proceedings and monetary penalties. The below discussion explains these powers:

\footnotetext{
27 An example of States measures on tackling land-based pollution on the marine environment is the 1992 Convention for the Protection of the Marine Environment of the North-East Atlantic (also known as the OSPAR Convention).

${ }^{28}$ See $\mathrm{n} 7$ above, p. 137: Report of the International Law Commission on the work of its eight session (A/3159), II YB ILC 1956, at 253, 299.

${ }^{29}$ See $\mathrm{n} 1$ above, art. 208 (3).

30 The 'Area' is defined under UNCLOS article 1 (1) as meaning the sea-bed and ocean floor and subsoil thereof, beyond the limits of national jurisdiction.

${ }^{31}$ See $\mathrm{n} 7$ above, p. 153.

${ }^{32}$ See $\mathrm{n} 1$ above, art. $194(5)$

${ }^{33}$ See $\mathrm{n} 1$ above, art. 210 (5).

${ }^{34}$ See also the Protocol of 1978 relating to the International Convention for the Prevention of Pollution from Ships of 1973 MARPOL 73/78 has six annexes dealing with vessel pollution. These are oil, noxious liquid substances carried in bulk, harmful substances carried in packaged form, sewage, and garbage and air pollution.
} 


\section{i) Detention}

A coastal State can detain a vessel where it believes that it is polluting the marine environment of the coastal State's maritime zones. This detention is temporary and is subject to an institution of a judicial proceeding. ${ }^{35}$ The vessel can also be detained when it does not comply with its given certificate, example "the condition of the ship or its equipment does not correspond substantially with the particulars of the certificate." 36 Article 220 in giving a right of detaining (when relevant) to the coastal State uses the term "may". This implies that, it is not a condition but rather a right. Thus, a coastal State is not under pressure to detain a concerned vessel, but other measures can be taken. This was ruled by a Swedish Supreme Court in a case of Capri Marine Ltd. V. Chief State Prosecutor $^{37}$ as such that:

Article 220 (5)-(6) cannot be interpreted as implying that a coastal state's jurisdiction over violations in its Exclusive Economic Zone is dependent on the adoption of coercive measures such as inspection or detention. ${ }^{38}$

Therefore detention is not a compulsory condition for a State rather than a right.

\section{ii) Demand of information from the infringing vessel}

The coastal State can ask the infringing vessel for relevant information such as its identity, port of registry, etc. ${ }^{39}$ Disclosure of information from the infringing vessel is a prerequisite condition to undertake physical inspection by the coastal State. ${ }^{40}$ As long as UNCLOS is concerned, it allows a State party to adopt regional, national and international regulations to deal with the prevention of the marine environment. With regard to information, the International Convention for the Prevention of Pollution from Ships of 1973 (MARPOL 73/78 Annex VI) explains that a State can require information of the fuel sample used by the ship. ${ }^{41}$ The coastal State can also choose to forward such information to a flag State as given under regulation 4 (2), 6 (3) and (4) of MARPOL.

\section{iii) Institute proceedings}

Foreign ships in innocent passage are protected from interference by a coastal State. ${ }^{42}$ Nevertheless, where certain grounds arises that the vessel is polluting the marine environment of a coastal State, the vessel can be inspected. ${ }^{43}$ Where evidence arises, the Coastal State can institute a suit or claim for damage of the marine environment caused by the vessel. ${ }^{44}$ Where States have not settled the dispute by recourse, ${ }^{45}$ one or both parties to the dispute can choose any court/tribunal as given under article 287 of the UNCLOS. These are:

a) the International Tribunal for the Law of the Sea (ITLOS),

b) the International Court of Justice (ICJ),

\footnotetext{
35 See $n 7$ above, p. 300.

36 See MARPOL on Enforcement.

37 Case No. 2004:26

38 S. Mahmoudi \& D. Caron 'Capri Marine Ltd. v. Chief State Prosecutor - Swedish Supreme Court decision on jurisdiction to impose pollution fees on owners or operators of ships operating in the exclusive economic zone' (2005) 99 American Journal of International Law 472-478.

39 See $n 1$ above, art. 220, par. 3.

40 See $n 1$ above, art. 220, par. 5.

41 See MARPOL, Annex VI, regulation 18 at 2.18.

${ }^{42}$ See $\mathrm{n} 1$ above, art. 223. See also TSC, art. 19

43 See $n 1$ above, art. 220

44 See $n 1$ above, art. 229

45 See n 1 above, art. 279-285.
} 
c) an arbitral tribunal (AT),

d) a special arbitral tribunal (SAT).

Examples of cases instituted at some of the above court/tribunal are: Nicaragua $v$. Honduras ${ }^{46}$ before the ICJ, Ireland v. United Kingdom ${ }^{47}$ before the ITLOS and Bluefin Tuna ${ }^{48}$ cases before the AT.

\section{iv) Monetary penalties}

The UNCLOS gives coastal States powers to impose monetary penalties on infringing vessels. ${ }^{49}$ This penalty must be imposed upon the infringing party where it has committed a wilful and serious act of pollution in the coastal States maritime zones. Nevertheless, the rights ${ }^{50}$ of the accused must be observed on imposition of fines.

The Swedish case of Capri Marine Ltd. V. Chief State Prosecutor ${ }^{51}$ consolidated three cases on allegations of polluting the Swedish EEZ by shipping activities. The Wind Spirit Marine Company was fined 54,900 kronor for oil discharge, the White Star was fined 73,800 kronor for water pollution and the Capri Marine was imposed a fine of 439,000 kronor for the discharge of oil. ${ }^{52}$

\section{Section Two: A Critical analysis of the powers: Does the UNCLOS really provide protection for the coastal states in terms of preventing marine pollution from shipping?}

Though UNCLOS illustrates six types of pollution, it follows that many of these sources passes through shipping activities. For example land-based discharges such as dumping and carrying of hazardous and noxious substances (HNS) are usually discharged by shipping. The same applies to the exportation of mines from the sea-bed.

The case laws ${ }^{53}$ as well as UNCLOS enjoin States to protect their maritime zones against pollution. UNCLOS obliges members to prevent marine pollution whether moved by intentional or non-intentional actions. As discussed before, the coastal State has powers to make regulations in order to protect its maritime environment from pollution from shipping or vessels. Nevertheless, the powers are not absolute as certain conditions are specified under the UNCLOS, such regulations must: ${ }^{54}$

i) not "apply to the design, construction, manning or equipment ${ }^{55}$ of foreign ships unless they are giving effect to generally accepted international rules or standards". ${ }^{56}$

ii) be duly publicised. ${ }^{57}$

\footnotetext{
${ }^{46}$ [1986] ICJ Rep. 14

47 (2002) 41 ILM 405

48 New Zealand v. Japan, Australia v. Japan (1999), 38 ILM 1624; Australia and New Zealand v. Japan (2000) 39 ILM 1359.

49 See $n 1$ above, article 230 (2).

50 These can include but not limited to right of being heard, defend and given information before the penalty takes effect.

${ }^{51}$ Case No. 2004:26

52 S. Mahmoudi \& D. Caron 'Capri Marine Ltd. v. Chief State Prosecutor - Swedish Supreme Court decision on jurisdiction to impose pollution fees on owners or operators of ships operating in the exclusive economic zone' (2005) 99 American Journal of International Law 472-478.

${ }^{53}$ See $\mathrm{n} 22$ above, p. 332; Corfu Channel (1949) ICJ Rep. and Trail Smelter arbitration (1941) III RIAA 1905.

${ }^{54}$ See n 22 above, p. 347.

55 Nevertheless some States enact regulations which are against this provision. Examples are Malaysia prohibiting the discharge of any oil, US requiring foreign ports to have double hulls. See Lowe, pp 352-353.
}

${ }^{56}$ See $\mathrm{n} 1$ above, art. 21 (2). 
iii) be non-discriminatory. ${ }^{58}$

iv) not hamper the innocent passage of foreign vessels. ${ }^{59}$

v) (where it is a strait) give 'effect to applicable international regulations regarding the discharge of oil, oily wastes and other noxious substances in the strait. ${ }^{, 60}$

The coastal State has powers in its territorial sea (both ice-covered areas and straits) and EEZ. The coastal state can take action against a vessel which is not innocent to the coastal State's marine environment. In such a situation, the coastal State can require information, inspect, arrest or institute judicial proceeding against the vessel. ${ }^{61}$ The coastal State is also given powers to adopt rules and regulation through the competent international organization which is the International Marine Organisation at the present. ${ }^{62}$ The powers to arrest, detain, inspect of the coastal State proves that the UNCLOS has given powers for the prevention of pollution of the marine environment from shipping.

The coastal State is also given powers to enact legislation which will provide measures to prevent marine pollution within its coastal zone. In doing so, the coastal State can enact new laws, adopt regional and international statutes. These legislations used by the coastal State must be a "means for the protection of the living resources of the sea from harmful agents." 63 Giving powers to the coastal State in making rules, standards, practices and procedures for the protection of the marine zones against vessels, proves that the UNCLOS has provided sufficient powers to the coastal State.

As discussed earlier, the UNCLOS clears a path for States to use other national and international guidelines. This allows a broader choice of using different provisions which expands the powers on the prevention of marine pollution. Such laws are International Convention for the Prevention of Pollution from Ships (MARPOL 73/78), ${ }^{64}$ regional conventions under the auspices of United Nations Environment Programme (UNEP), ${ }^{65}$ Territorial Sea Convention (TSC), ${ }^{66}$ International Maritime Organisation (IMO), ${ }^{67}$ just to mention a few. These treaties allow a State to implement them in its national laws so as to protect the marine environment. For example, article 18 (1) of the TSC provides that where the passage of a vessel is of a kind to disturb the peace of the country or the good order of the territorial sea, then the coastal State can use its criminal jurisdiction. Some examples of the regional treaties are the Helsinki Convention, ${ }^{68}$ Barcelona Convention for the protection of the Mediterranean Sea and Protocols ${ }^{69}$ and Kuwait Convention. ${ }^{70}$ Thus, the use of regional and international

57 See $n 1$ above, art. 21 (3).

58 See $\mathrm{n} 1$ above, art. 24.

59 See n 1 above, art. 211 (4)

${ }^{60}$ See $\mathrm{n} 1$ above, art. 42 (1).

${ }^{61}$ See $\mathrm{n} 1$ above, art. 220 and 233.

${ }^{62}$ See $\mathrm{n} 1$ above, article 211 (1).

${ }^{63}$ See $\mathrm{n} 1$ above, article 5 (7).

64 A Protocol of 1978 relates to prevent pollution from ships.

65 A programme established in 1978. It deals with not only marine issues, but also other environmental issues such as atmosphere and ecosystems.

${ }^{66}$ (Geneva) Made in 1958 and entered into force in 1964. Matters of the territorial sea are much explained in this Convention.

${ }^{67}$ This Convention was adopted in Geneva in 1948. It maintains a comprehensive regulatory framework for shipping such as security, efficiency, technical co-operation etc. See www.imo.org for more information.

68 This convention is on the protection of the marine environment of the Baltic sea area of 1992 (Helsinki Convention). See regulation $\mathrm{n} 5$ (a) and (b) on reporting procedure of harmful substances from shipping crew to the coastal State.

${ }_{69}$ This Protocol was concluded in 1994. Requires authorisation of all sea-bed activities, carrying out of environmental impact assessments. See $n 1$ above, art. 4-8; also see n 22 above, p. 373.

70 This Convention was adopted in 1989. It provides provisions on oily drainage water, garbage and sewage. See also n 22 
treaties which are authorised under the UNCLOS gives wide actions for the coastal State to protect its maritime zone against marine pollution.

Article 235 of the UNCLOS provides that damage of the marine environment from shipping should be compensated to the victim. The same is provided in the UNEP guidelines as well as the Helsinki Convention. ${ }^{71}$ Therefore, "the victims of pollution from sea-bed operations should be able to obtain effective compensation for the damage they have suffered.",72

The UNCLOS under article 194 (5) give powers to a coastal State in protecting their territorial sea in areas which have unique species such as "habitat of depleted, threatened or endangered species and other forms of marine life". For example the East African Protocol ${ }^{73}$ clearly state that State parties have a duty to conserve endangered species such as the fauna and flora. This Protocol is a product of the UNCLOS. Therefore, the UNCLOS powers of the coastal State are also extended to special species.

Spills from vessel were put into discussion mainly after the incidence of the Torrey Canyon. ${ }^{74}$ This casualty is described in part XII of the UNCLOS which deals with the protection of the marine environment (including spills from vessels). ${ }^{75}$ Many States have been affected by such spills. For example the "Nakhodka spill off Japan in 1997, the Prestige spill off France in 1999, the Erika spill off Spain in 2003 and the Hebei spill of South Korea in $2007^{, 76}$ are some incidences of such spills. These spills can contain chemicals and oil substances which will affect the marine resources. Where they are not regulated, they will obviously pollute the maritime environment. Therefore actions must be taken by both, the concerned ship and the coastal State. In such a case, the vessel is required to make a detailed checklist of its ship before departure.

Given the powers to inspect a vessel, the coastal State can impose penalties to a vessel which is contrary to the safe passage on marine environment. As long as this study covers international law, it is therefore worth referring to a case from the USA in Exxon Shipping co. v. Baker ${ }^{77}$ before the Supreme Court of the United States. In this case, it was decided that Exxon should pay the victims for economic losses of about US\$ 500 million. Another famous incidence is during the 90's where the Vista Bella sank in the eastern Caribbean causing a discharge of heavy fuel (named no. 6). The discharge caused the presence of oil on beaches and "regularly occurring tar balls (2-5 inches) mixed in with the sea grass and sand between Muddy Point and Dieppe Bay.",78

The UNCLOS also covers dumping of hazardous wastes which is prohibited under article 210 of the UNCLOS. A state where the hazardous discharge of land waste has come from is responsible for the damages under international law. ${ }^{79}$ The most important thing for liability of such state is that "there must be a breach of an

above, p. 373

71 See art. 25 of the Helsinki Convention of 2008.

72 See n 22 above, p. 376.

73 This Protocol is concerned with the protected areas and wild fauna and flora in the western African region, adopted in Nairobi in 1985, see arts. 3 and 4.

74 (1967) Cmnd. 3246.

75 See $n 1$ above, arts 235 and 235 (3).

76 N. Gaskell \& C. Forrest 'Marine pollution damage in Australia: Implementing the Bunker Oil Convention 2001 and the supplementary fund protocol 2003' (2008) 27 Queensland L.J 103.

77544 U.S (2008).

78 NOAA - Hazardous Materials Response and Assessment Division, Report no. HMRAD 92-11 Summaries of significant U.S. and International spills: Oil Spills Case History 1967-1991, (Washington: 1992), p. 210.

${ }^{79}$ M. Qing-nan, Land-Based Marine Pollution, (Kluwer: London, 1987) p. 84. 
international obligation, regardless of its source either in customary rules or treaty obligations." 80 Since UNCLOS is an international convention derived from the UN, any infringement of the duty not to dump hazardous wastes into the coastal state will lead to an action being taken by the coastal state. The infringing party will also be responsible under strict liability or through the exhaustion of local remedies. ${ }^{81}$ Annex $\mathrm{V}$ of MARPOL specifies a distance from land that is required to dispose of its wastes and methods of waste disposal. It also imposes complete ban of dumping plastic into the sea.

\section{Conclusion}

As from the discussion, the coastal State has powers to detain, institute proceedings, receive sufficient information and claiming monetary damages from an infringing vessel. In major harmful situations, article 221 (1) of the UNCLOS extends these powers of the coastal State beyond the territorial sea. This concludes that the coastal State has sufficient powers to protect its marine zones against pollution caused by vessels.

\section{References}

A. Berret 'UNCLOS III: Pollution Control in the Exclusive Economic Zone,' 55 (1994-1995) Louisiana Law Review 1165-1190.

A. Boyle 'Further Development of the Law Sea Convention: Mechanisms for Change' (2005) 54 (3) ICLQ 563-584.

A. Boyle 'Marine Pollution under the Law of the Sea Convention' (1985) 79 American Journal of International Law 347-372.

J. Charney 'The Marine Environment and the 1982 United Nations Convention on the Law of the Sea' (1994) 28 Int'l L 879- 902.

M. McConnell and E. Gold 'The Modern Law of the Sea: Framework for the Protection and Preservation of the Marine Environment?' (1991) 23 Case W. Res. J. Int. 83-105.

D. Torrens 'Protection of the Marine Environment in International Law: Toward an Effective Regime of the Law of the Sea' (1993-1994) 19 Queen's Law Journal 613-654.

\footnotetext{
${ }^{80}$ See $\mathrm{n} 79$ above, p. 85.

${ }^{81}$ See $\mathrm{n} 79$ above, p. 89.
} 